\title{
Analysis of Enterprise Operation Under the Impact of COVID-19 Epidemic: A Case Study of Nike Inc.
}

\author{
Sihan Meng ${ }^{1, \dagger}$ Beichen $\mathrm{Wei}^{2, \dagger}$ Gaozhen $\mathrm{Xu}^{3, \dagger}$ Ruimeng Zhang ${ }^{4, *}, \dagger$ \\ ${ }^{1}$ School of Economics and Management, North China University of Technology, Beijing 100144, China \\ ${ }^{2}$ School of Accounting, Henan University of Economics and Law, Zhengzhou, Henan 457000, China \\ ${ }^{3}$ School of Business, Sun Yat-Sen University, Guangzhou, Guangdong 510000, China \\ ${ }^{4}$ Wellington School of Business and Government, Victoria University of Wellington, Wellington 6011, New Zealand \\ these authors contributed equally \\ *Corresponding author. Email: zhangruim@myvuw.ac.nz
}

\begin{abstract}
The outbreak of Coronavirus Disease 2019 (COVID-19) brought a significant negative impact on the global economic and social development, where many enterprises are generally facing operational difficulties. Among all the corporations, Nike Inc.'s practice in the face of major public safety accidents has practical significance and enlightenment for the business management of enterprises and countries. Based on the combination of quantitative and qualitative research methods, this paper discusses the short-term negative impacts of major public health emergencies on Nike Inc. According to the ratio analysis, Nike Inc.'s performance in profitability is pretty well. Regarding to the SWOT analysis, it turns out that Nike Inc. has low manufacturing cost and advantages in marketing and sales. However, it still needs to pay attention to single core competitiveness and high price. This article provides feasible reference ideas for multinational enterprises and countries to deal with major public security incidents. On this basis, these results are useful for enterprises to eliminate the negative impact of the epidemic on their operations. Besides, it will be helpful for countries to protect their economic achievements and create a better business environment in the face of crisis.
\end{abstract}

Keywords: COVID-19, Nike Inc., quantitative and qualitative research methods, short-term, negative impact, enterprise operation.

\section{INTRODUCTION}

The COVID-19 outbreak in the first half of 2020 caused a systemic economic standstill, with some companies experiencing operational and financial difficulties, i.e., operational difficulties have appeared in many enterprises. The short-term negative impact of major public health emergencies on enterprises mainly focuses on the impact on the revenue and production cost of enterprises. From the perspective of business operation, when a major public health emergency breaks out, the market demand shrinks, and the order demand of downstream enterprises transfers to other countries, which will reduce the business income of enterprises. After a long period of shutdown Many enterprises are under great cost pressure in the process of resuming work due to the insufficient capital flow, and faced with the situation of making ends meet. The circulation of raw materials needed by enterprises is blocked, the return time of labor force to work is continuously delayed, and normal business activities (e.g., production and sales) are restricted. Meanwhile, the production efficiency of enterprises is reduced owing to employee absenteeism caused by the virus infection and the shutdown measures adopted by the government (prevent the further spread of the virus), i.e., further affected the business income of enterprises. In addition, the shutdown control caused by major public health emergencies makes the upstream raw material supply chain of enterprises disrupted, the price of raw materials increased, and the production cost of enterprises increased. At the same time, major public health emergencies bring additional epidemic prevention costs to the production and operation of enterprises, reducing the profits of enterprises. Major public health emergencies will also increase the capital demand of enterprises and increase the capital cost of enterprises.

Scholar Xiao studied the cash holdings of enterprises under the COVID-19 epidemic, which found that the COVID-19 epidemic affected the market's expectation of the future cash flow of enterprises [1]. Besides, the 
preventive value of corporate cash holdings was more prominent when the external environment was poor [1]. During the epidemic period, the social risk level increased, the circulation speed of social capital slowed down, the return of corporate capital was blocked, and the risk of capital chain breaking increased [2]. Nurul Mohammad Zayed et al. argued that the massive decline of world economy in 2020 could be recovered by the faster global and local recovery rates of economic activity in 2021 with the whole world awareness and cooperation [3]. Wu Feng et al showed that changes in total consumer demand and the consumption model caused by COVID-19 will lead to a short-term decline in consumption, investment, and employment, as well as a rise in prices. Delayed resumption of work and production and transportation controls reduce labor input, causing labor wages to rise, enterprise production costs to increase and supply to fall. In addition, COVID19 affects international trade through its impact on global production supply chains. Gerald Ileka and Massomeh Hajilee indicated the need for governments to use a fiscal policy that involves changes to taxes and higher spending to boost people's incomes and trigger growth through higher consumption. Thus, the economic challenges of the COVID-19 pandemic have caused a decline in the globalization of consumption but a fiscal policy will be useful in overcoming the problems and enabling nations to resume growth [4]. Karmaker Chitra Lekha, et al. stated that policy development considering health protocols and automation is essential for long-term sustainability in supply chains (SCs) [5].

In general, from the perspective of research content, the existing literatures focus more on the operating difficulties faced by the whole industry under the impact of major public health emergencies [6]. Besides, the number of literatures considering the impact of the outbreak of the epidemic on specific enterprises is relatively small [6]. From the perspective of research methods, most of the literature adopts the normative analysis method, and there are few quantitative analysis papers. The main reason for these problems is that there is still a dearth of data on targeted corporate surveys.

This paper takes Nike Inc. as the research object and studies its corporate strategy in the context of COVID19. Through the combination of quantitative and qualitative research methods, this paper discusses the short-term negative impact of major public health emergencies on Nike Inc.

\section{DATA AND METHOD}

\subsection{Data}

To investigate the COVID-19 impact on Nike Inc.'s business, it is expected to extract all the financial information and operation details needed from the 2018 to 2020 financial statements of Nike Inc., free Internet information resources as well as disclosure related to the industrial chain in Nike Inc.'s annual reports.

Nike Inc. is a world famous company of sports shoes and apparels, leading the industry with over $28 \%$ of market share in 2019. [7] The company has various kinds of sports products, including almost all kinds of sports. The company's customers are from all over the world. It has retail stores and subsidiaries in many countries around the globe, making its name heard worldwide. Nike Inc. focuses its production on six major categories: Running, Nike Inc. Basketball, the Jordan Brand, Football (Soccer), Training and Sportswear as well as products of other kinds of sports.

Nike Inc.'s operating segments are evidence of the structure of the company's internal organization. The Nike Inc. brand segments are defined by geographic regions for operations participating in Nike Inc. brand sales activity. The company's reportable operating segments for the Nike Inc. brand are North America; Europe, Middle East \& Africa (EMEA); Greater China; and Asia Pacific \& Latin America (APLA), and this includes results for the Nike Inc. and Jordan brands, with results for the Hurley Brand, prior to its divestiture, included in North America. Each Nike Inc. brand geographic segment operates predominantly in one industry: the design, development, marketing and selling of athletic footwear, apparel and equipment.

Nike Inc., formally founded in 1972 by Bill Bowerman and his alumnus Philip Knight, headquartered in Oregon, USA, is a famous sporting goods manufacturer. It is the industry leader in the design, sales and operation of sports footwear, apparel, equipment and accessories for all kinds of sports and fitness activities.

\subsection{Method}

\subsubsection{Quantitative Analysis}

In this paper, Nike Inc.'s latest financial situation and the COVID-19 impact on Nike Inc.'s financial statements can be evaluated and identified based on quantitative method. Ratios from four aspects will be discussed including profitability, efficiency, liquidity, and solvency. The ratios and their formulas are listed in Table. 1

Table 1. Profitability Ratios

\begin{tabular}{l|l}
\hline $\begin{array}{l}\text { Return on common } \\
\text { equity }\end{array}$ & $\begin{array}{l}\text { net income/shareholders } \\
\text { equity }\end{array}$ \\
\hline Return on assets & net income/total assets \\
\hline Return on investment & net income/investment \\
\hline
\end{tabular}




\begin{tabular}{l|l} 
Earnings per share & $\begin{array}{l}\text { net income/outstanding } \\
\text { common stock }\end{array}$ \\
\hline Profit margin & net income/revenue \\
\hline
\end{tabular}

There are five ratios used to best determine Nike Inc. Inc.'s profitability. Return on common equity (ROCE) can be defined as the amount of net income returned as a percentage of shareholders equity. Return on common equity (ROCE) measures a corporation's profitability by revealing how much profit a company generates with the money shareholders have invested [8].

Table 2. Efficiency Turnover Ratios

\begin{tabular}{l|l}
\hline Asset turnover & sales/average assets \\
\hline $\begin{array}{l}\text { Accounts } \\
\text { payable turnover }\end{array}$ & $\begin{array}{l}\text { credit purchase/average } \\
\text { accounts payable }\end{array}$ \\
\hline $\begin{array}{l}\text { Accounts } \\
\text { receivable } \\
\text { turnover }\end{array}$ & $\begin{array}{l}\text { credit sales/average accounts } \\
\text { receivable }\end{array}$ \\
\hline $\begin{array}{l}\text { Inventory } \\
\text { turnover }\end{array}$ & $\begin{array}{l}\text { cost of goods sold/average } \\
\text { inventory }\end{array}$ \\
\hline $\begin{array}{l}\text { Working capital } \\
\text { turnover }\end{array}$ & sales/average working capital \\
\hline
\end{tabular}

There are five ratios to identify the efficiency of the company as well (listed in Table 2). Asset turnover is a ratio that measures the efficiency of a company's use of its assets. Accounts payable turnover shows a company's ability to pay off its accounts payable and indicates how quickly a company pays off its vendors. Accounts receivable turnover measures of how efficiently a company can collect on the credit it extends to customers. Inventory turnover is a measure of the number of times inventory is sold or used in a time period. Working capital turnover measures how the company is using its working capital to support a given level of sales.

Table 3. Liquidity and Solvency Ratios

\begin{tabular}{l|l}
\hline current ratio & current assets/current liabilities \\
\hline quick ratio & liqiud assets/current liabilities \\
\hline Interest coverage & EBIT/interest expense \\
\hline \multirow{2}{*}{ Leverage } & assets/equity \\
\cline { 2 - 2 } & assets/liabilities \\
\cline { 2 - 2 } & liabilities/equity \\
\hline
\end{tabular}

Liquidity ratio measures the ability of a company to meet its short-term debt obligations and it is the ability to convert assets into cash quickly and cheaply. There are two main metrics to measure liquidity, which are current ratio and quick ratio. On the other hand, solvency ratios are concerned with longer term ability to pay ongoing debts. There are interest coverage and leverage rates to measure a company's solvency. Interest coverage analysis depends largely on how much risk the creditor or investor is willing to take. Financial leverage is the degree to which the firm utilizes its fixed-income securities and uses equity to financial projects. Companies with high leverage are usually considered to be at financial risk.

\subsubsection{Qualitative Analysis}

After ratio analysis, SWOT analysis model is used to estimate the industry and strategy of Nike Inc. SWOT analysis is a framework used to evaluate a company's competitive position and to develop strategic planning. [9] It assesses internal and external factors, as well as current and future potential. A SWOT analysis is designed to facilitate a realistic, fact-based, data-driven look at the strengths and weaknesses of an organization, initiatives, or within its industry. The organization needs to keep the analysis accurate by avoiding pre-conceived beliefs or gray areas instead focusing on real-life contexts. Companies should use it as a guide and not necessarily as a prescription.

Analysts present a SWOT analysis as a square segmented into four quadrants as illustrated in Fig, 1 drawn by ourselves, where each dedicated to an element of SWOT. This visual arrangement provides a quick overview of the company's position. Although all the points under a particular heading may not be of equal importance, they all should represent key insights into the balance of opportunities and threats, advantages and disadvantages, etc..

\begin{tabular}{|l|l|}
\hline S & W \\
Strength & Weakness \\
\hline O & \\
\hline Opportunity & Threat \\
\hline
\end{tabular}

Figure 1. SWOT Model

\section{RESULTS AND DISCUSSION}

This part will mainly discuss the operating conditions of Nike Inc. under the environment of COVID-19 through a series of financial analysis, which are carried out from two aspects of quantitative analysis and qualitative analysis. The overall objective is to deduce an assessment of the recent operating and financial situation of Nike Inc. The quantitative analysis is based on Nike Inc.'s financial reports and other Internet secondary data to calculate the indicators of profitability, efficiency, liquidity and solvency of Nike Inc. in the last three years. The qualitative analysis is presented following the 
information disclosed by Nike Inc., Nike Inc. earnings call transcripts of the recent three years, intuition and experience of the analyst, related policy and external assessments of Nike Inc. In this case, we make a detailed analysis of the overall internal and external competitive environment, operating strategy and soft power of the enterprise. The detailed method of quantitative analysis and qualitative analysis are ratio analysis and SWOT analysis.

\subsection{Quantitative Analysis}

\subsubsection{Profitability Ratio Analysis}

Table 4. The calculation results of five main profitability ratios of Nike Inc. in fiscal year 2018, 2019, and 2020.

\begin{tabular}{|l|l|l|l|}
\hline \multicolumn{4}{|c|}{ Profitability Ratio Analysis } \\
\hline & $\mathbf{2 0 2 0}$ & $\mathbf{2 0 1 9}$ & $\mathbf{2 0 1 8}$ \\
\hline $\begin{array}{l}\text { Return on Common } \\
\text { Equity (ROCE) }\end{array}$ & 31.52 & 44.57 & 19.70 \\
\hline & 14.54 & 32.22 & 14.56 \\
\hline $\begin{array}{l}\text { Earnings per share } \\
\text { (EPS) }\end{array}$ & 1.60 & 2.49 & 1.17 \\
\hline $\begin{array}{l}\text { Return on Assets } \\
\text { (ROA) }\end{array}$ & 8.10 & 16.99 & 8.58 \\
\hline Profit Margin (PN) & 6.79 & 10.30 & 5.31 \\
\hline
\end{tabular}

There are five ratios used to best determine Nike Inc.'s profitability. For Nike Inc., the data has shown a trend of fluctuations, but overall moving forward. Return on assets (ROA) is an indicator of how profitable a company is relative to its total assets. It is calculated by dividing a company's operating earnings by its total assets [10]. From Table 4, it is seen that the trend for Nike Inc. is hard to define because of the high ratio in 2019, but it is basically the same but with a slight decrease between 2018 and 2020. Return on investment (ROI) is a ratio between net income and investment, and a high return on investment (ROI) means the investment's gains compare favorably to its cost [11]. For Nike Inc. as suggested in Table 4, the results of 2018 and 2020 are pretty much the same other than its high ratio in 2019. Earnings per share (EPS) is used to value the monetary earnings per common stock for a company, and higher earnings per share (EPS) means better performance[12]. The earnings per share (EPS) of Nike Inc. has shown a trend of increasing, i.e., it is a good sign. Profit margin $(\mathrm{PM})$ is one of the most important and useful tools to determine the profitability of a company [13], and Nike Inc.'s profit margin (PM) indicates a positive trend.
Overall, the profitability of Nike Inc. in 2018 and 2020 are similar but with an improvement, and the year that is most profitable is 2019 .

The reason why profit margin (PM) increased from fiscal 2018 to 2019 is that Nike Inc. adopted the strategy of "asset-light", which is considerably favored by enterprises all over the world since proposed. Moreover, it means that Nike Inc. outsourced the manufacturing and retailing of products and the company itself concentrates on products research and development in the market [14]. Nike Inc. is one of the earliest companies adopting the strategy of asset-light, and it did make great progress in the matter of making profit [15]. Another reason is because Nike Inc. had done some research and development of products earlier, so ever since fiscal 2018, the company acquired more profit. From 2019 to 2020, Nike Inc.'s performance decreased because of the negative impact of COVID-19. During that time, Nike Inc. lacked innovation on products, while its competitors such as Adidas Inc. and Under Armour Inc. had more competitive advantages at the same time [16].

\subsubsection{Efficiency Ratio Analysis}

Table 5. The calculation results of five main efficiency ratios of Nike Inc. in fiscal year 2018, 2019, and 2020.

\begin{tabular}{|l|l|l|l|}
\hline \multicolumn{4}{|c|}{ Efficiency Ratio Analysis } \\
\hline & 2020 & $\mathbf{2 0 1 9}$ & $\mathbf{2 0 1 8}$ \\
\hline Asset Turnover & 1.19 & 1.65 & 1.62 \\
\hline $\begin{array}{l}\text { Accounts Payable } \\
\text { Turnover }\end{array}$ & 9.41 & 8.29 & 8.97 \\
\hline $\begin{array}{l}\text { Accounts } \\
\text { Receivable } \\
\text { Turnover }\end{array}$ & 13.61 & 9.16 & 10.41 \\
\hline $\begin{array}{l}\text { Inventory Turnover } \\
\text { Working Capital }\end{array}$ & 2.87 & 3.85 & 3.89 \\
\hline \begin{tabular}{l} 
Turnover \\
\hline
\end{tabular} & 3.05 & 4.52 & 4.00 \\
\hline
\end{tabular}

There are five ratios to identify the efficiency of the company. Asset turnover is a ratio that measures the efficiency of a company's use of its assets [17]. Table 5 suggests that Nike Inc.' efficiency has been decreasing, which is not a good thing to happen. Accounts payable turnover shows a company's ability to pay off its accounts payable and indicates how quickly a company pays off its vendors [18]. The accounts payable turnover of Nike Inc. has been increasing while surprising decreasing in 2019. This is a sign of the company growing too fast and cannot pay back its debtors fast enough, which needs to be improved in the future. Accounts receivable turnover measures of how 
efficiently a company is able to collect on the credit it extends to customers [19]. The efficiency has improved from 2018 to 2020 while with a decline in 2019 as shown in Table 5. This means the same thing as accounts payable turnover, which is an effect caused by how quickly the company has been growing. It is necessary to collect money faster, i.e., Nike Inc. should consider improving this when the same situation like 2019 happens again. Inventory turnover is a measure of the number of times inventory is sold or used in a time period [20]. Surprisingly, the efficiency of selling inventory has decreased from 2018 to 2020 this can be seen in Table 5 and it suggests some improvements needed to implement. Working capital turnover measures how the company is using its working capital to support a given level of sales [21]. From Table 5, it is seen that the trend of Nike Inc.'s working capital turnover has been decreasing, and it is a potential problem for the company. Overall, the efficiency of the company is tricky, but there are indeed some limitations that need to be considered.

For efficiency and turnover ratios, Nike Inc. had better management on account receivable and it made that account receivable turnover increased by 0.58 percent by adopting the strategy of cash discount. For inventory turnover, outsourcing manufacturing sections made Nike Inc. do not have any physical factory or inventory itself attributed to the light asset strategy, i.e., any activities related to those are reduced. Another reason was that Nike Inc. allows retailers to place orders five to six months in advance, guaranteeing that $90 \%$ of orders will arrive at a set price and in a set time [22]. This strategy has been successful in minimizing inventory and reducing inventory turnover as much as possible as well.

\subsubsection{Liquidity Ratio Analysis}

Table 6. The calculation results of two main liquidity ratios of Nike Inc. in fiscal year 2018, 2019, and 2020.

\begin{tabular}{|l|l|l|l|}
\hline \multicolumn{4}{|c|}{ Liquidity Ratio Analysis } \\
\hline & 2020 & $\mathbf{2 0 1 9}$ & $\mathbf{2 0 1 8}$ \\
\hline Current Ratio & 2.48 & 2.10 & 2.51 \\
\hline Quick Ratio & 1.59 & 1.39 & 1.63 \\
\hline
\end{tabular}

Liquidity ratio measures the ability of a company to meet its short-term debt obligations and it is the ability to convert assets into cash quickly and cheaply [23]. There are two main metrics to measure liquidity, which are current ratio and quick ratio. The Table 6 shows that the current ratio and quick ratio all have a trend of decreasing in fiscal year 2019 and increasing in fiscal year 2020. This is a good sign as there will be a positive effect if the liquidity ratios get higher since they measure a firm's ability to repay the debt in the short term [24]. In this case, the higher the ratios, the better it is to the company. For Nike Inc., it had a good performance for 2020 but there are some problems for the fiscal year of 2019. Compared with its competitor, Adidas Inc., the current ratios of the two companies are almost the same [25]. They both had a stable level on the aspect of short term liquidity ratios. However, compared with the average level of industry, Nike Inc. had a trend of weaker performance. The reason might be that Nike Inc. lacked some strategies on operational and capital structure management.

\subsubsection{Solvency Ratio Analysis}

Table 7. The calculation results of four main solvency ratios of Nike Inc. in fiscal year 2018, 2019, and 2020.

\begin{tabular}{|l|l|l|l|}
\hline \multicolumn{4}{|c|}{ Solvency Ratio Analysis } \\
\hline & 2020 & 2019 & 2018 \\
\hline $\begin{array}{l}\text { Interest Coverage } \\
\text { (NI) }\end{array}$ & 35.00 & 97.39 & 82.31 \\
\hline $\begin{array}{l}\text { Leverage: Assets to } \\
\text { Equity }\end{array}$ & 3.89 & 2.62 & 2.30 \\
\hline $\begin{array}{l}\text { Leverage: Liabilities } \\
\text { to Assets }\end{array}$ & 0.74 & 0.62 & 0.56 \\
\hline $\begin{array}{l}\text { Leverage: Liabilities } \\
\text { to Equity }\end{array}$ & 2.89 & 1.62 & 1.30 \\
\hline
\end{tabular}

Liquidity ratio measures short-term debt, while solvency ratios are concerned with longer term ability to pay ongoing debts [26]. There are interest coverage and leverage rates to measure a company's solvency. Interest coverage analysis depends largely on how much risk the creditor or investor is willing to take [27]. Nike Inc.'s interest coverage ratio increased from 2018 to 2019 and decreased from 2019 to 2020 listed in Table 7. It indicates that Nike Inc. had a positive trend for fiscal year 2019, but it had some problems for fiscal year of 2020 because the interest coverage rate is expected to be higher year by year. Compared with the average level of industry and its competitors, Nike Inc. has a relatively stable level of performance on the aspect of long term solvency ratios [28].

In the meantime, Nike Inc.'s financial leverage is the degree to which the firm utilizes its fixed-income securities and uses equity to financial projects. Companies with high leverage are usually considered to be at financial risk [29]. Nike Inc.'s financial risk is the risk to Nike Inc.'s stockholders that is caused by an increase in debt. Since all three of Nike Inc.'s leverage rates have been increasing, it is safe to say that Nike Inc. had a high interest payment that therefore reduced earnings per share. However, it is hard to say whether it 
is good or bad for a company to have higher or lower leverage because leverage only measures the relative amounts of debt and equity [29]. Companies could have more debts compared with equities because of its lower cost, and it may have another positive effect such as tax reduction. Nevertheless, having more debts would lead to serious results (e.g., bankruptcy), which will bring financial stress for companies. If the debt of a firm increases constantly, then there may be some problems on cash operation. For Nike Inc., the leverage of liabilities to equities is increasing, which does not mean the operation of cash incurred some problems. In fact, its cash cycle became shorter and Nike Inc. made progress on the aspect of cash management, which is almost the same as compared with the average level of industry. Nike Inc. has overall achieved improvements in its strategy of cash management.

\subsection{Qualitative Analysis of the Soft Power of Nike Inc.}

This part will demonstrate the SWOT model results in order to make a detailed analysis of the overall internal and external competitive environment and soft power of Nike Inc. Four quadrants of SWOT model are strengths, weaknesses, opportunities, and threats. The results of analysis are listed in Table 5 below.

\subsubsection{Strengths}

First of all, Nike Inc. has low manufacturing cost. Adopting the mode of outsourcing production and manufacturing from 1970 s, more than $90 \%$ of Nike Inc. shoes production is contracted in third countries, mostly in Asian, so it does not have factory itself. It makes Nike Inc. get a multitude of cheaper labor, i.e., it can get much discounts from suppliers and save much cost. Although the cooperation with the third countries is affected by the COVID-19 to some extend, it does not impact the advantage of outsourcing of Nike Inc. In addition, Nike Inc. has been in the business of sportswear for decades, during which Nike Inc. has obtained economies of scale since it has a multitude of products manufactured and shipped to all over the world. Thus, the overall manufacturing cost of Nike Inc. is relatively low [30]. Secondly, marketing and sales are one of the core competitiveness of Nike Inc. Nike Inc.'s marketing strategy has been constantly changing according to the preferences of consumers. Nike Inc. can keep up with the changing tendency of the market and make rapid and accurate response. Nike Inc. also cooperates with many celebrities, e.g., famous athletes, designers and artists. As a result, the brand value of Nike Inc. has been enhanced.

\subsubsection{Weaknesses}

First of all, single core competitiveness is one of the most iconic weaknesses of the company. Nike Inc. has a wide range of sports products. However, the company's revenue still mainly depends on its share of the footwear market. The turbulence of the footwear market will have a huge impact on the operation of Nike Inc. If the market share of footwear shrinks for any reason, it will be greatly affected. Compared with the strong competitiveness of the main competitor of Nike Inc. in the footwear market, Adidas Inc., the risk of Nike Inc. is relatively high. Secondly, the unsuitable product price for some people is another weakness of Nike Inc. The high quality of Nike Inc. sports products determines its high price, which is also a weakness of Nike Inc. Most of the price of a single Nike Inc. product is more than 200 yuan, which discourages some consumers with lower spending power. Faced with the strong rise of sportswear brands today, coupled with the popularization of national sports, sports are no longer a demand of the nobles. The sports equipments of Nike Inc. are relatively expensive (Nike Inc. shoes are more expensive than domestic brandshalf), i.e., the majority of ordinary people are beyond sight. This is the biggest obstacle to its continued expansion of market share $[31,32]$.

\subsubsection{Opportunities}

First of all, with the trend of globalization, the encryption of contracts between countries gives the industry of sports shoes and apparels opportunity. International expansion is a huge opportunity to bring faster growth to the brand for Nike Inc. with the favorable policy of international expansion. If the operations of Nike Inc. span the globe, with each office servicing a large geographic area in multiple countries, especially some first-tier cities, Nike Inc. can operate well according to local habit and culture. In addition, sports are spreading rapidly all over the world, and it is becoming fashionable. This provides extremely rare and huge opportunities for sports goods manufacturers. Hence, the prospects of Nike Inc., a global giant in sports goods, will certainly be brighter [33]. The second opportunity is acquirement. Brands grow faster by acquiring relevant business. With the negative impact of COVID-19, many small and medium-sized companies and start-ups are still in poor operating and financial situation, and even some are hard to continue to operate. With the vast financial resources of Nike Inc. and the favorable policy of combining small and medium-sized companies, it can acquire some small and medium-sized companies or start-ups to gain a more efficient value chain.

\subsubsection{Threats}

Despite the dominance of Nike Inc. in the sports industry, leading the market with over $20 \%$ of the market share, its competitors are still chasing. In other words, the competition and emerging brands remain a potential threat to the company. Nike Inc. will face competition 
from companies like Adidas and Under Armour, which are in roughly equal size and power with Nike Inc. Unlike Nike Inc., both these two companies were spending more on $\mathrm{R} \& \mathrm{D}$, marketing and innovation, continuing to make products more different in functions. the competition in the industry is relatively high. It is easy for most of customers of Nike Inc. to switch to other brands. For most of the customers of Nike Inc., there is no huge difference among products of sportswear companies since they are not professional enough to fully utilize the features. The professional athletes only take up a little share in the sales of Nike Inc. Comparing with competitors of Nike Inc., Nike Inc.'s product differentiation is normal. Thus, for most of customers of Nike Inc., switching to other brands is easy. Therefore, the increase in competition becomes a threat for Nike Inc [34].

Table 8. SWOT Analysis of Nike Inc.

\begin{tabular}{|l|l|}
\hline Strengths & Weaknesses \\
\hline Low Manufacturing Cost & $\begin{array}{l}\text { Single Core } \\
\text { Competitiveness }\end{array}$ \\
\hline Marketing and Sales & Relatively High Price \\
\hline Opportunities & Threats \\
\hline International Expansion & Emerging Brands \\
\hline Acquirement & Increase in Competition \\
\hline
\end{tabular}

\section{CONCLUSION}

\subsection{Conclusion and Ideas}

From the ratio analysis, it is shown that Nike Inc.'s performance in profitability is exhibiting well, while its efficiency is decreasing to a certain extent. As for the liquidity and solvency ratios, Nike Inc.'s short-term debt coverage is increasing, while long-term debt coverage is decreasing. According to the quantitative analysis, it is obvious that COVID-19 is not affecting Nike Inc.'s profitability as much as people think. This is probably due to two main reasons. Firstly, COVID-19 happens mainly in the fourth quarter of fiscal 2020, which was largely off set by the enhancement in performance in the nine months before. In addition, until the end of fiscal 2020, $100 \%$ of Nike Inc.'s stores in Greater China has reopened, supporting Nike Inc.'s business a lot. However, from the perspective of efficiency and debt coverage, it is clear that Nike Inc.'s not performing as it did in profitability. These results can probably come from the huge number of stores and factories closed affected by the quarantine policies around the globe. These situations will terribly affect Nike Inc.'s operation.

Turning to the SWOT analysis, the conclusion is that some of Nike Inc.'s strengths and weaknesses, opportunities, and threats will change under the influence of COVID-19. First, Nike Inc.'s efficient inventory management as well as timely deliveries and shipments as its advantages can be affected since many parts of the world is under quarantine and will keep on being like that for a period. However, further investment in global sourcing team can become greater opportunity because a global supply chain can diversify the risk brought by the quarantine policy of certain regions. Meanwhile, during the time of pandemic, Nike Inc. should pay more attention to customers since they are the key to the revival of its business.

\subsection{Article Contribution}

Nike Inc.'s practice in the face of major public safety accidents has practical significance and enlightenment for the business management of enterprises and countries. Based on above analysis, the epidemic has caused extensive and lasting negative impact on Nike Inc.'s business, mainly reflected in the decline of operating revenue and the increase of production costs. Nevertheless, the magnitude of the impact is waning compared to when the outbreak began. This is mainly due to Nike Inc. timely strategic adjustment in the outbreak stage, increase liquidity and efficiency, risk allocation and actively develop online channels, accelerate the process of digitalization. Additionally, it also makes the Nike Inc. smoothly through the outbreak and reopen the offline stores basic maintain their growth.

This paper is also of universal significance. At the enterprise level, the epidemic has awakened sales enterprises to develop multiple sales and publicity channels. Increasing sales volume is one of the difficulties Nike Inc. faces during the epidemic. Nike Inc. should pay attention to the establishment of online platform sales model, vigorously build online sales network and improve the logistics efficiency of the enterprise. Meanwhile, in addition to the traditional ecommerce platform, network broadcast with goods is also an important way. Live broadcasting is more suitable for product sales. In the form of live broadcasting, it can bring consumers intuitive feelings and wider market for Nike Inc. It is an essential self-help measure to embrace "online" in time. Thirdly, management efficiency. The COVID-19 epidemic has put forward higher requirements for the management efficiency of enterprises, just as Nike Inc.'s current development focus is to introduce digital management, build strong competitiveness, reduce the operating cost of enterprises to the greatest extent, and improve the efficiency of market and consumer feedback.

In the face of major public safety accidents, the state should also give full support to enterprises. At the government policy level, the downturn in market demand due to the epidemic is the primary factor causing the decline in operating income and profits of enterprises. To 
maximize the effect of pro-business policies, governments need to combine support for businesses with boosting market demand. Therefore, it is necessary to simultaneously introduce policies oriented to the market demand side to rebuild consumer confidence and enhance consumption willingness. On the one hand, the increase of publicity of the implementation and effect of epidemic prevention policies to reduce the public's fear of the epidemic and avoid excessive epidemic prevention measures to suppress the consumption will of consumers. Moreover, consumer subsidies can be given to increase consumers' willingness to consume by issuing consumer vouchers and other means. On the other hand, in the aspect of product supply, enterprises are encouraged to guide the release of consumer demand by means of promotion and improving customer experience according to product characteristics. In order to revive the vitality of consumption, it is necessary to enhance the overall market purchasing power, help enterprises through the difficult period. Meanwhile, the country ought to consider the path to establish an emergency response model to minimize the loss of major public safety accidents and create a good living environment for enterprises.

Taking Nike Inc. as an example, it provides feasible reference ideas for multinational enterprises and countries to deal with major public security incidents. Furthermore, these results will offer a guideline for enterprises to eliminate the negative impact of the epidemic on their operations, and helps countries to protect their economic achievements and create a better business environment in the face of crisis.

\section{REFERENCES}

[1] Xiao, T., Sun, R., \& Yuan, C. (2020). The Preventive Value of Corporate Cash Holdings Under the Impact of the Outbreak of the New Crown Pneumonia.Economic.Management(04),175-191.

[2] Wu, F., Liu, G., Guo, N., Li, Z., \& Deng, X. (2021). The impact of COVID-19 on China's regional economies and industries. Journal of Geographical Sciences(04),565-583.

[3] Zayed, N. M., Khan, S., Shahi, S. K., \& Afrin, M. (2021). Impact of Coronavirus (COVID-19) on the World Economy, 2020: A Conceptual Analysis. Journal of Humanities, Arts and Social Science, (1),

[4] Ileka, G., \& Hajilee, M. (2021). The COVID-19 Pandemic Impact on Global Economy. Journal of Global Economics(3),

[5] Lekha, K. C., Tazim, A., Sayem, A., Mithun, A. S., Abdul, M., \& Golam, K. (2021). Improving supply chain sustainability in the context of COVID-19 pandemic in an emerging economy: Exploring drivers using an integrated model. Sustainable Production and Consumption,.

[6]Li, H., Wu, Y., Qiu, W., \& Gan, L. (2020). The Impacts of COVID-19 on China's Small and Medium-Sized Enterprises:A Progress Report.Bulletin of National Natural Science Foundation of China, (06),747-759.

[7] Technavio. (2019). Nike Market Share in 2019: World's Largest Shoe Company, https://blog.technavio.com/blog/nike-market-shareworlds-largest.

[8] Barnes, P. (1987). The analysis and use of financial ratios. Journal of Business Finance and Accounting, 14(4), 449-461.

[9] Leigh, D. (2009). SWOT analysis. Handbook of Improving Performance in the Workplace: Volumes $1-3,115-140$.

[10] Petersen, M. A., \& Schoeman, I. (2008, July). Modeling of banking profit via return-on-assets and return-on-equity. In Proceedings of the World Congress on Engineering (Vol. 2, pp. 1-6).

[11] Phillips, P. P., \& Phillips, J. J. (2009). Return on investment. Handbook of Improving Performance in the Workplace: Volumes 1-3, 823-846.

[12] Patell, J. M. (1976). Corporate forecasts of earnings per share and stock price behavior: Empirical test. Journal of accounting research, 246-276.

[13] Fairley, W. B. (1979). Investment income and profit margins in property-liability insurance: Theory and empirical results. The Bell Journal of Economics, 192-210.

[14] Sohn, J., Tang, C. H. H., \& Jang, S. S. (2013). Does the asset-light and fee-oriented strategy create value?. International Journal of Hospitality Management, 32, 270-277.

[15] Surdu, G. (2011). The internationalization process and the asset-light approach. Romanian Economic and Business Review, 6(1), 184.

[16] Prévost-Surprenant, A. (2020). Analyse: La dynamique compétitive entre un leader global et un challengeur en processus d'internationalisation. Le cas de Nike et de Under Armour.

[17] Supardi, H., Suratno, H. S. H., \& Suyanto, S. (2018). Pengaruh Current Ratio, Debt to Asset Ratio, Total Asset Turnover dan Inflasi Terhadap Return on Asset. JIAFE (Jurnal Ilmiah Akuntansi Fakultas Ekonomi), 2(2), 16-27. 
[18] Ortín-Ángel, P., \& Prior, D. (2004). Accounting turnover ratios and cash conversion cycle. Problems and perspectives in management, (1), 189-205.

[19] Gorczyńska, M. (2011, September). Accounts Receivable Turnover Ratio. The Purpose of Analysis in Terms of Credit Policy Management. In 8th International Scientific Conference on Financial Management of Firms and Financial Institutions, Ostrava, Czech Republic.

[20] Rao, M. C., \& Rao, K. P. (2009). Inventory turnover ratio as a supply chain performance measure. Serbian Journal of Management, 4(1), 41-50.

[21] Ginting, W. A. (2018). Analisis Pengaruh Current Ratio, Working Capital Turnover, dan Total Asset Turnover Terhadap Return On Asset. VALID Jurnal Ilmiah, 15(2), 163-172.

[22] Arora, R., \& Aggarwal, G. (2012). OPERATIONS MANAGEMENT AT NIKE: FROM BREAKDOWN TO ACHIEVEMENT. International Journal of Management Research and Reviews, 2(7), 1293.

[23] Breuer, A., Frumusanu, M. L., Breuer, B. L., \& Manciu, A. (2012). Cash and liquidity/liquidity and liquidity ratio. Annals-Economy Series, 4, 78-82.

[24] Healey, P. (1987). Liquidity analysis and management. Reading, Mass.; Don Mills, Ont.: Addison-Wesley Pub.

[25] Khatik, S. K., \& Nag, A. K. (2020). Financial Performance Appraisal of Adidas Group. Indian Journal of Research in Capital Markets, 7(4), 19-25.

[26] Russell, L. A., Langemeier, M. R., \& Briggeman, B. C. (2013). The impact of liquidity and solvency on cost efficiency. Agricultural Finance Review.

[27] Dothan, M. (2006). Costs of financial distress and interest coverage ratios. Journal of Financial Research, 29(2), 147-162.

[28] Yao, D. W., \& Chen, X. (2019). Nike inc.-footware and apparel (Doctoral dissertation).

[29] Kraus, A., \& Litzenberger, R. H. (1973). A statepreference model of optimal financial leverage. The journal of finance, 28(4), 911-922.

[30] Donaghu, M. T., \& Barff, R. (1990). Nike just did it: International subcontracting and flexibility in athletic footwear production. Regional studies, 24(6), 537-552.

[31] Ramaswamy, V. (2008). Co-creating value through customers' experiences: the Nike case. Strategy \& leadership.
[32] Katz, D. R. (1994). Just do it: The Nike spirit in the corporate world (p. 336). New York: Random House.

[33] Sage, G. H. (1999). Justice do it! The Nike transnational advocacy network: Organization, collective actions, and outcomes. Sociology of Sport Journal, 16(3), 206-235.

[34] Mahdi, H. A. A., Abbas, M., Mazar, T. I., \& George, S. (2015). A Comparative Analysis of Strategies and Business Models of Nike, Inc. and Adidas Group with special reference to Competitive Advantage in the context of a Dynamic and Competitive Environment. International Journal of Business Management and Economic Research, 6(3), 167177. 